DOI https://doi.org/10.32837/app.v63i0.21

УДК 343.138 .5

Пилипенко С. В. ${ }^{*}($ НУ «ОЮА»)

\title{
УХВАЛА СУДУ ПРО ПОВЕРНЕННЯ ОБВИНУВАЛЬНОГО АКТУ, КЛОПОТАННЯ ПРО ЗАСТОСУВАННЯ ПРИМУСОВИХ ЗАХОДІВ МЕДИЧНОГО АБО ВИХОВНОГО ХАРАКТЕРУ ПРОКУРОРУ: ПРОБЛЕМИ ПРАКТИКИ ТА НОРМАТИВНОЇ РЕГЛАМЕНТАЦЇ̈ \\ COURT ORDER ON THE RETURN OF THE APPROVAL ACT, REQUESTS FOR THE APPLICATION OF MEDICAL OR EDUCATIONAL PREPARATORY MEASURES TO PROSECUTOR: PROBLEMS OF PRACTICE AND NORMATIVE REGULATION
}

*Sergii Pylypenko - PhD Student (Law), Criminal Process Department, National University “Odesa Law Academy” (23, Fontanska Doroha St., Odesa, Ukraine).

\section{Abstract}

The article is devoted to the study of the problems of practice and legal regulation of the issuance by the courts of orders on the return of the indictment, petitions for the use of compulsory measures of medical or educational nature to the prosecutor. The expediency of introducing the following amendments and additions to the current CPC of Ukraine, which will promote the effective proceedings and ensure the rights and freedoms of persons in it: to supplement paragraph 3 of Part 3 of Art. 314 of the CPC "petitions for release from criminal liability", as well as "annexes, provided by this Code", which will give legal grounds for deciding on their return, if they do not meet the requirements of the CPC; add article 314 of the CCP, the norm of sending a revoked indictment, a petitions for the use of compulsory measures of a medical or educational nature, a petition for release from criminal liability, in case of their re-submission after their correction, that's why the judge (court), who ordered the decision on their return. 
Keywords: court orders; pre-trial proceedings; indictment; petitions for the use of compulsory measures of an educational or medical nature; court decisions.

Постановка проблеми. Доступ до правосуддя та право кожного на справедливий судовий розгляд та вирішення справи в розумні строки передбачає створення державою механізмів забезпечення належної правової процедури, яка унеможливлює призначення матеріалів кримінальних проваджень до судового розгляду, що не відповідають вимогам кримінального процесуального кодексу України (далі - КПК).

Однією з таких процедур є інститут повернення обвинувального акту, клопотань про застосування примусових заходів медичного чи виховного характеру прокурору. Від того наскільки належною буде правова регламентація цієї процедури залежить ефективність засади доступу до правосуддя та законність провадження взагалі. Недоліки діючого КПК у цьому питанні обумовлюють деякі практичні проблеми ефективного застосування цього інституту та наукову і практичну потребу дослідження рішення суду про повернення обвинувального акту, клопотань про застосування примусових заходів медичного чи виховного характеру прокурору.

Аналіз останніх досліджень. Проблемам інституту судових рішень в кримінальному провадженні присвятили свою увагу такі вчені як В.М. Беднарська, О.І. Бережний, Г.І. Богонюк, Н.В. Глинська, І.В. Гловюк, С.В. Глущенко, Д.О. Захаров, О.В. Ігнатюк, Н.В. Кіцен, О.В. Костюченко, І.І. Котубей, Ю.В. Охотіна, В.В. Смірнова, С.М. Смоков, Х.В. Тайлієва, В.І. Теремецькій, Ю.М. Харковець, О.3. Хотинська, В.I. Чорнобук, В.В. Шумов та ін.

Дослідження підготовчого провадження активізувалися з прийняттям КПК України 2012 р., у якому цей інститут зазнав істотних змін у напрямі взаємоузгодження із змагальним характером судового розгляду. Зокрема, Ю. П. Аленін, В. І. Бояров, В. І. Галаган, Н. В. Глинська, І. В. Глов'юк, С. І. Дячук, О. В. Сні, О. В. Капліна, В. В. Король, О. П. Кучинська, В. В. Лисенко, В. В. Луцик, Л. Г. Матієк, І. В. Назаров, В. Т. Нор, В. О. Попелюшко, В. В. Рожнова, Д. О. Савицький, Н. П. Сиза, Л. Д. Удалова, Г. О. Усатий, О. Г. Шило, О. Г. Яновська та ін. безпосередньо чи побічно, у їх взаємозв' язку з суміжними правовими інститутами, торкалися окремих його аспектів. Також було захищені деякі кандидатські дисертації $з$ цієї тематики («Оціночна діяльність судді у підготовчому провадженні» (2015 р.) - 
О.В. Калужинський; «Підготовче провадження в кримінальному процесі України» (2016 р.) - О.Ф. Шминдрук).

Разом $з$ тим, проблемам винесення судом ухвал про повернення обвинувального акту, клопотань про застосування примусових заходів медичного чи виховного характеру прокурору приділена недостатня увага, залишаються такі проблеми як недостатньо чітка регламентація підстав та процедури винесення такого рішення, які породжують практичні проблеми застосування цього інституту.

Формулювання цілей статті. Метою цієї статті $є$ визначення деяких проблем правозастосування інституту повернення обвинувального акту, клопотань про застосування примусових заходів медичного чи виховного характеру прокурору, недоліків його правової регламентації та формулювання пропозиції щодо удосконалення законодавства та практики у цьому напрямку.

Виклад основного матеріалу. Для того, щоб з'ясувати сутність такого рішення як повернення обвинувального акту, клопотань про застосування примусових заходів медичного чи виховного характеру прокурору, необхідно визначити взагалі призначення і завдання взагалі стадії, на якій це рішення ухвалюється.

Як зазначив Л.М. Лобойко, процесуальне значення підготовчого провадження як стадії кримінального процесу полягає у наступному: 1. Стадія є свого роду «процесуальним фільтром» судового провадження, не допускаючи до судового розгляду матеріали досудового розслідування, якщо вони не відповідають закону. 2. У ній визначаються межі майбутнього судового розгляду. Розгляд справи по суті у суді першої інстанції може відбутися тільки за тим обвинуваченням, що було представлене прокурором у підготовчому провадженні. 3. Підготовче провадження забезпечує створення всіх необхідних умов для правильної організації і успішного проведення судового засідання (Лобойко, 2014, с. 276). Серед основних завдань підготовчого провадження як стадії кримінального провадження виділяють: перевірку наявності процесуальних підстав для затвердження угоди про визнання винуватості чи про примирення, перевірку наявності підстав для закриття провадження, перевірку відповідності вимогам кримінального процесуального закону обвинувального акта, клопотання про застосування примусових заходів медичного чи виховного характеру, перевірку дотримання правил визначення підсудності кримінального провадження, підготовку умов для успішного проведення судового розгляду (Кримінальний процесуальний кодекс України. Науково-практичний коментар: у 2 т. Т. 2, с. 312). 
Н.П. Сиза виділяє такі завдання підготовчого провадження: 1) перевірка відповідності процесуальних документів, поданих прокурором, вимогам кримінального процесуального закону; 2) розгляд скарг та клопотань учасників кримінального провадження; 3) з'ясування наявності підстав для завершення кримінального провадження; 4) встановлення відсутності порушень вимог кримінального процесуального закону, що перешкоджають призначенню судового розгляду; 5) вирішення питань, пов' язаних з підготовкою до судового розгляду (Сиза, 2014).

Отже, всі вчені сходяться у тому, що одним із завдань є перевірка відповідності процесуальних документів, поданих прокурором, вимогам кримінального процесуального закону. Відповідно за результатами такої перевірки суд, згідно ч. 3 ст. 314 КПК України уповноважений прийняти рішення про повернення обвинувального акту, клопотання про застосування примусових заходів медичного або виховного характеру прокурору, якщо вони не відповідають вимогам КПК.

Слід зазначити, що діючий КПК досить поверхово регламентує як порядок підготовчого провадження, так і підстави прийняття судом відповідних рішень у цій стадії, що обумовлює певні практичні проблеми правозастосування. Деякі роз'яснення порядку підготовчого провадження наданні у інформаційному листі Вищого спеціалізованого суду України з розгляду цивільних і кримінальних справ від 03 жовтня 2012 року «Про порядок здійснення підготовчого судового провадження відповідно до Кримінального процесуального кодексу України» (Інформаційний лист Вищого спеціалізованого суду України з розгляду цивільних і кримінальних справ від 03 жовтня 2012 року «Про порядок здійснення підготовчого судового провадження відповідно до Кримінального процесуального кодексу України»).

Якщо суд встановить, що кримінальне провадження підсудне цьому суду, він повинен перейти до перевірки обвинувального акта, клопотання про застосування примусових заходів медичного або виховного характеру вимогам ст. ст. 285-287, 291, 292 КПК.

Необхідно зазначити, що чинний КПК не включає до цього переліку клопотання прокурора про звільнення від кримінальної відповідальності, проте, суд за аналогією зобов'язаний перевірити також і це клопотання. Така позиція підтримана серед науковців (Луцик, 2010, с. 1), а також підтверджується судовою практикою деяких судів. Такими підставами не раз визнавалися випадки: невідповідності клопотання вимогам ст. 287 КПК, а саме - в ньому не було зазначено 
доказів, які підтверджують факт вчинення Особою_1 кримінального правопорушення, а також не додана письмова згода особи на звільнення ії від кримінальної відповідальності (Ухвала Святошинського районного суду м. Києва від 25 лютого 2014 року); невідповідності клопотання до п. 4 ч.1 ст. 287 КПК України, а саме - не вказано місця вчинення кримінального правопорушення, що унеможливлює правильне визначення підсудності (вала Корецького районного суду Рівненської області від 19 серпня 2015 року); обвинувачений не визнав себе винним у вчиненні інкримінованого йому злочину, не дав згоду на звільнення його від кримінальної відповідальності на підставі ст. 48 КК України у зв 'язку із зміною обстановки (Ухвала БілгородДністровського міськрайонного суду Одеської області від 28 березня 2019 р.); клопотання не містить відомостей про ознайомлення 3 цим ним потерпілих та їхню думку щодо можливості звільнення підозрюваного ОСОБА_3 від кримінальної відповідальності; не містить воно і місця фактичного проживання кожного з потерпілих, що позбавляє суд належним чином повідомити їх про день, час та місце розгляду даного клопотання та з'ясувати їх думку про можливість звільнення ОСОБА_3 від кримінальної відповідальності (Ухвала Дарницького районного суду м. Києва від 06 липня 2018 р.).

Задля створення належних правових підстав таких судових рішень вважаємо доцільним доповнити п. 3 ч. 3 ст. 314 КПК словосполученням «клопотання про звільнення від кримінальної відповідальності».

Підставами повернення обвинувального акта, клопотання про застосування примусових заходів медичного або виховного характеру, клопотання про звільнення від кримінальної відповідальності прокурору деякі вчені вважають встановлення судом істотних формальних порушень вимог кримінального процесуального закону (Шминдрук, 2016, с. 109). Під істотними формальними порушеннями кримінального процесуального закону слід розуміти такі обмеження чи позбавлення прав учасників процесу, або порушення встановлених законом вимог до форми та змісту кримінальних процесуальних актів, які не стосуються всебічності та повноти проведеного досудового розслідування, та які можна усунути безпосередньо прокурором без проведення слідчих дій (Луцик, 2010, с. 15).

На думку О.Б. Комарницької та В.К. Радіонова, підстави повернення обвинувального акта можна поділити на такі групи: 1) організаційноформального характеру; 2) невідповідність нормам КПК України 
(ст. ст. 291, 293, 109, 110); 3) неузгодженість між собою рівних за значенням законодавчих актів; 4) різне право розуміння та правозастосування КПК України (Комарницька, Радіонов, 2015, с. 74).

Вимоги до змісту обвинувального акту містяться в ст. 291 КПК України. До обвинувального акта обов' язково мають бути додані додатки, передбачені цією ж статтею КПК. Невідповідність цих вимог КПК є підставою для повернення обвинувального акта прокурору. Проте тлумачення цих вимог судами є досить різними.

Наприклад, ухвалою Хмельницького міськрайонного суду від 26 грудня 2014 року, залишеною без змін ухвалою Апеляційного суду Хмельницької області від 11 лютого 2015 року, було повернуто обвинувальний акт прокурору та вказано: «Підставою повернення обвинувального акта стала невідповідність його вимог п. 5 ч. 2 ст. 291 КПК України, а саме - обвинувальний акт має містити виклад фактичних обставин кримінального правопорушення, які прокурор вважає встановленими, правову кваліфікацію кримінального правопорушення з посиланням на положення закону і статті (частини статті) закону України про кримінальну відповідальність та формулювання обвинувачення. Формулювання обвинувачення має бути викладено так, щоб чітко були зазначені основні обставини, які підлягають доказуванню у кримінальному процесі, зокрема, подія кримінального провадження (час, місце, спосіб та інші обставини вчинення кримінального правопорушення) - п. 1 ч. 1 ст. 91 КПК України. Як свідчать матеріали кримінального провадження, обвинувальний акт щодо Особи_1 вказаним вимогам не відповідає. Так, в обвинуваченні, висунутому Особі_1 не зазначено, в який спосіб останній, за попередньою змовою з не встановленими слідством особами, вчинив напад на потерпілого, спричинивши йому легкі тілесні ушкодження 3 короткочасним розладом здоров'я та відкрите заволодіння майном потерпілого, спричинивши йому легкі тілесні ушкодження» (Ухвала Хмельницького міськрайонного суду Хмельницької області від 26 грудня 2014 року).

Тут необхідно зазначити, що суд, повертаючи обвинувальний акт 3 підстави, передбаченої п. 5 ч. 1 ст. 291 КПК, не повинен входити в кримінально-правову оцінку діяння особи, а також оцінку доказів, що інколи відбувається на практиці. Так, в ухвалі Апеляційного суду Рівненської області від 24 лютого 2015 року, якою було скасовано увалу Здолбунівського районного суду Рівненської області від 29 січня 2015 року про повернення обвинувального акта прокурору було 
зазначено, що висновок суду першої інстанції про наявність в обвинувальному акті неправильної правової кваліфікації обвинувачення, на думку колегії суддів, є безпідставним, оскільки суд першої інстанції вийшов за межі тих питань, які підлягають вирішенню під час підготовчого судового засідання, зокрема, щодо обставин, які характеризують об'єктивну сторону інкримінованого кримінального правопорушення та впливають на доведеність винуватості, про що правомірно йдеться в апеляційній скарзі прокурора. Фактичні обставини кримінального правопорушення, відповідно до вимог закону, підлягають встановленню виключно під час судового розгляду шляхом дослідження наданих сторонами кримінального провадження доказів, а порушені питання в підготовчому судовому засідання щодо правильності та обгрунтованості кваліфікації дій обвинуваченого, без судового розгляду кримінального провадження i дослідження доказів $є$ передчасними та не грунтуються на вимогах чинного законодавства» (Ухвала Апеляційного суду Рівненської області від 24 лютого 2015 року).

Неоднозначною також була судова практика щодо повернення обвинувального акта прокурору з підстави невідповідності реєстру досудового розслідування вимогам ст. 109 КПК України. 3 початку дії чинного КПК суди досить часто повертали обвинувальні акти 3 підстав неправильного чи неповного складання реєстру матеріалів досудового розслідування. Так, в ухвалі Київського районного суду м. Одеси зазначено, що в порушення ст. 109 КПК України реєстр матеріалів досудового розслідування містить протиріччя та неповний перелік процесуальних дій і процесуальних рішень. В реєстрі матеріалів досудового розслідування відсутні відомості: про складання обвинувального акту; відсутнє процесуальне рішення про визнання та долучення до матеріалів кримінального провадження речових доказів по справі та відомості про місце їх знаходження; про залучення до матеріалів кримінального провадження про складання клопотання про продовження строку досудового розслідування; п. п. 19, 20, 21 розділу II не мають даних щодо посадової особи, яка прийняла рішення; відсутні відомості щодо додаткового допиту підозрюваного 19.08.2016 року; в розділі III не зазначено строк застосування заходів забезпечення, некоректно заповнена графа «Вид заходу», а графи «хто обрав» та «дата обрання» не відповідають змісту; відсутні відомості про процесуальне рішення щодо виділення матеріалів досудового розслідування відносно невстановленої особи 246 
в окреме провадження, що має істотне значення для кваліфікації дій обвинуваченого (Ухвала Київського районного суду м. Одеси від 16.12.2016 року).

Проте $є$ і протилежна практика. Так, ухвалою Апеляційного суду Рівненської області від 05 травня 2015 року було скасовано ухвалу Сарненського районного суду Рівненської області від 01 квітня 2015 року про повернення обвинувального акта прокурору з підстави невідповідності реєстру матеріалів досудового розслідування вимогам ст. 109 КПК та направлено обвинувальний акт із реєстром матеріалів досудового розслідування до того ж суду для здійснення судового провадження з формулюванням: «Відповідно до п. 3 ч. 3 ст. 314 КПК України, у підготовчому судовому засіданні суд має право повернути обвинувальний акт прокурору, якщо він не відповідає вимогам цього Кодексу. Зі змісту цієї норми закону чітко випливає, що єдиною передбаченою законом підставою для повернення обвинувального акту прокурору є невідповідність цього акта вимогам зазначеного Кодексу. При цьому, варто звернути увагу на те, що закон не передбачає підставою для повернення обвинувального акта прокурору факт невідповідності вимогам закону будь-яких додатків до цього акту чи інших суміжних документів (реєстру, цивільного позову, розписок, доданих матеріалів кримінального провадження тощо)» (Ухвала Апеляційного суду Рівненської області у справі № 572/734/15-к від 05 травня 2015 року).

3 цього приводу В.В. Колодчин висловлює точку зору, що суд під час підготовчого провадження вправі перевірити лише факт наявності реєстру матеріалів досудового розслідування, а не його зміст. Відсутність реєстру є безумовною підставою для повернення обвинувального акта (або іншого підсумкового документу) прокурору на доопрацювання, проте недоліки у самому реєстрі не можуть бути розцінені як підстава для такого судового рішення (Колодчин, 2015, с. 9).

В цілому не можемо погодитися з цим і вважаємо, що обвинувальний акт разом із реєстром матеріалів досудового розслідування та іншими документами формують собою матеріали кримінального провадження, що в подальшому будуть предметом дослідження у підготовчому провадженні та судовому розгляді, у зв'язку з чим невідповідність цих матеріалів вимогам КПК повинна також бути підставою для повернення цих документів прокурору, оскільки дуже часто тягнуть за собою порушення прав і свобод людини та неможливість проведення судового розгляду у розумні строки. Проте для 
цього, необхідно передбачити більш чітку правову регламентацію питання повернення обвинувального акта прокурору у зв' язку із невідповідністю його додатків вимогам КПК, щоб унеможливити таку негативну практику.

Дискусійним є питання визначення судом строку, протягом якого мають бути усунуті прокурором вказані недоліки в ухвалі про повернення обвинувального акта або відповідних клопотань. Судова практика з цього приводу не характеризується одностайністю. Так, в зазначеному інформаційному листі (Інформаційний лист Вищого спеціалізованого суду України з розгляду цивільних і кримінальних справ від 03 жовтня 2012 року «Про порядок здійснення підготовчого судового провадження відповідно до Кримінального процесуального кодексу України») зазначається, що ухвалою про повернення матеріалів кримінального провадження (обвинувального акта, клопотання про застосування примусових заходів медичного або виховного характеру) суд зобов' язує прокурора усунути виявлені недоліки протягом визначеного ним розумного строку, який має бути достатнім для виправлення допущених недоліків. Проте це протиріччить ст. ст. 314-317 КПК, які не наділяють суддів повноваженнями для встановлення будь-якого строку для виправлення недоліків.

В.В. Луцик висловлює точку зору про необхідність законодавчого закріплення строків для усунення прокурором недоліків процесуальних документів, оскільки законодавче встановлення строку для усунення недоліків буде дисциплінувати прокурора і сприятиме реалізації таких принципів кримінального процесу, як законність та змагальність сторін (Луцик, 2009, с. 18).

На нашу думку, слід підтримати Д.В. Пономаренко, який зазначає, що встановлення строків для усунення недоліків обвинувального акта не відповідає вимогам КПК, адже після його повернення прокурору, останній теоретично може прийняти рішення про закриття провадження. Однак відповідно до ухвали суду, в якій визначено строк, прокурор змушений знову направити обвинувальний акт до суду, що суперечить вимогам КПК (Пономаренко, 2016, с. 11).

Інша проблема це виконання зазначеної категорії ухвал, тобто виправлення зазначених в них помилок і недоліків обвинувального акту та відповідних клопотань. Практиці відомі випадки неодноразово повернутих обвинувальних актів, які знов надходять до суду без їх належного виправлення. Так, в ухвалі Голосіївського районного суду м. Києва від 28.02.2018 року зазначено, що обвинувальний акт уже 248 
неодноразово повертався прокурору, однак недоліки обвинувального акта не були усунуті. Суд в черговий раз вимушений звертати увагу прокурора на ту обставину, що до обвинувального акта долучено розписку обвинуваченого про отримання обвинувального акта від 23.01.2018 року та копії реєстру без дати ії складання. Однак, зазначена розписка по суті є оригіналом ксерокопій розписок, яка уже долучалася до обвинувального акта складеного ще 29.10.2015 року та 26.10.2017 року, що ставить під обгрунтований сумнів обставини реального вручення обвинуваченому обвинувального акта від 23.01.2018 року, що є обов' язковим (Ухвала Голосіївського районного суду м. Києва від 28.02.2018 року).

Варто зауважити, що така неоднаковість судової практики повернення обвинувальних актів прокурору обумовлена як об' єктивними чинниками (особливостями кожної справи), так і суб'єктивними. На практиці зустрічаються випадки різного роду зловживань з боку деяких суддів, які у підготовчому провадженні під різними формальними приводами і підставами повертають обвинувальні акти або відповідні клопотання прокурорам, намагаючись таким чином уникнути розгляду по суті складних, проблемних або резонансних справ. Хоча КПК й передбачає механізм оскарження таких ухвал суду (ч. 4 ст. 314), проте це все одно затягує провадження у справі, і до того ж, такі судді де-факто добиваються своїх недобросовісних цілей, оскільки навіть при скасуванні апеляційним судом такої ухвали, система автоматичного документообігу, вірогідніше за все, призначить це провадження іншому судді. Тому для підвищення ефективності боротьби з цим негативним явищем, вважаємо доцільним запропонувати доповнити КПК нормою, яка б передбачала направлення повернутого обвинувального акту або відповідних клопотань після їх виправлення тому судді (суду), який приймав ухвалу про їх повернення.

Висновки. В результаті дослідження проблем практики та правової регламентації винесення судами ухвал про повернення обвинувального акту, клопотань про застосування примусових заходів медичного чи виховного характеру прокурору, вважаємо доцільним запропонувати наступні зміни до діючого КПК України, які були обгрунтовані в цьому досліджені та сприятимуть ефективному провадженню та забезпечення прав і свобод осіб у ньому:

1) п. 3 ч. 3 ст. 314 КПК викласти у наступній редакції: «nовернути обвинувальний акт, клопотання про застосування примусових 
заходів медичного або виховного характеру, клопотання про звільнення від кримінальної відповідальності прокурору, якщо вони або передбачені цим Кодексом додатки, не відповідають вимогам ицього Кодексу»;

2) доповнити ст. 314 КПК частиною п'ятою наступного змісту: «Повернутий обвинувальний акт, клопотання про застосування примусових заходів медичного або виховного характеру, клопотання про звільнення від кримінальної відповідальності, у випадку їх повторного подання після їх виправлення, подається тому судді (суду), який постановив ухвалу про їх повернення».

\section{Лiтература:}

Інформаційний лист Вищого спеціалізованого суду України з розгляду цивільних і кримінальних справ від 03 жовтня 2012 року «Про порядок здіисснення підготовчого судового провадження відповідно до Кримінального проиесуального кодексу України». <https://zakon.rada.gov.ua/laws/ show/v1430740-12>.

Колодчин В. В. (2015). Повноваження прокурора в судовому провадженні у першій інстанції: авторефер. дис... канд. юрид. наук: 12.00.09. Х.

Комарницька О. Б., Радіонов В. К. (2015). Актуальні питання повернення обвинувальних актів та прийнятих за цим рішень. Вісник прокуратури, 6 (168), 73-85.

Кримінальний процесуальний кодекс України. Науково-практичний коментар: у 2 m. Т. 2 (2012). За заг. ред. В. Я. Тація, В. П. Пшонки, А. В. Портнова. Х.: Право.

Лобойко Л. М. (2014). Кримінальний процес: підручник. К.: Вид. «Ітиина».

Луцик В. В. (2009). Повернення кримінальної справи прокурору зі стадіі попереднього судового розгляду: автореф. дис... канд. юрид. наук: 12.00.09. K.

Луцик В. В. (2010). Повернення кримінальної справи прокурору в процесі розгляду кримінальних справ, направлених для вирішення питання про звільнення особи від кримінальної відповідальності. Часопис Академї адвокатури Украӥни, 9 (4), 1-5.

Пономаренко Д. В. (2016). Без елементів немає злочину. Закон $і$ бізнес, 13 (1256), 9-13.

Сиза Н. П. (2014). Завдання суду в стадії підготовчого провадження у кримінальному процесі України. Часопис Національного університету 
«Острозька академія». Серія «Право», 2 (10). <http://lj.oa.edu.ua/ articles/2014/n2/14snpkpu.pdf>.

Ухвала Апеляційного суду Рівненської області від 24 лютого 2015 року. Єдиний державний реєстр судових рішень. <http:/ / www.reyestr.court.gov.ua/ Review/42829960>.

Ухвала Апеляційного суду Рівненської області у справі № 572/734/15-к від 05 травня 2015 року. Єдиний державний реєстр судових рішень. <http://www.reyestr.court.gov.ua/Review/43948528>.

Ухвала Білгород-Дністровського міськрайонного суду Одеської області від 28 березня 2019 р. Рішення для бізнесу - YouControl. <https://youcontrol.com.ua/catalog/court-document/80819273/>.

Ухвала Голосіївського районного суду м. Києва від 28.02.2018 року. Єдиний державний реєстр судових рішень. <http://www.reyestr.court. gov.ua/Review/72509927>.

Ухвала Дарницького районного суду м. Києва від 06 липня 2018 р. Єдиний державний реєстр судових рішень. <http://www.reyestr.court. gov.ua/Review/75416982>.

Ухвала Київського районного суду м. Одеси від 16.12.2016 року. VERDICTUM - ЛIГА:ЗАКОН. <https://verdictum.ligazakon.net/ document/63498750>.

Ухвала Корецького районного суду Рівненської області від 19 серпня 2015 року. Єдиний державний реєстр судових рішенъ. <http:/ / www.reyestr.court.gov.ua/Review/54974193>.

Ухвала Святошинського районного суду м. Києва від 25 лютого 2014 року. Єдиний державний реєстр судових рішень. <http:/ / www.reyestr.court.gov.ua/Review/37333759>.

Ухвала Хмельницького міськрайонного суду Хмельницької області від 26 грудня 2014 року. Єдиний державний реєстр судових рішень. <http://www.reyestr.court.gov.ua/Review/43352461>.

Шминдрук О. Ф. (2016). Підготовче провадження в кримінальному проиесі України: дис.... канд. юрид. наук: 12.00.09. Острог.

\section{References:}

Informacijny j ly'st Vy'shhogo specializovanogo sudu Ukrayiny z rozglyadu cy'vil'ny'x i kry'minal ny'x sprav vid 03 zhovtnya 2012 roku «Pro poryadok zdijsnennya pidgotovchogo sudovogo provadzhennya vidpovidno do Kry 'minal nogo procesual nogo kodeksu Ukrayiny'» [Information Letter 
of the High Specialized Court of Ukraine on Civil and Criminal Cases of 03 October 2012 "On the Procedure for Preparatory Court Proceedings under the Criminal Procedure Code of Ukraine"]. <https:/ / zakon.rada. gov.ua/laws/show/v1430740-12>. [in Ukrainian].

Kolodchy`n V. V. (2015). Povnovazhennya prokurora v sudovomu provadzhenni u pershij instanciyi: avtorefer. dy 's... kand. yury'd. nauk: 12.00 .09 [authority of the prosecutor in court proceedings at first instance: author's abstract. diss.... Cand. lawyer. Sciences: 12.00.09]. X. [in Ukrainian].

Komarny`cz`ka O. B., Radionov V. K. (2015). Aktual`ni py`tannya povernennya obvy`nuval`ny`x aktiv ta pry`jnyaty`x za cy`m rishen [Topical issues related to the return of indictments and the decisions taken thereon]. Visny 'k prokuratury '[Bulletin of the Prosecutor's Office], 6 (168), 73-85. [in Ukrainian].

Kry'minal 'ny j procesual 'ny j kodeks Ukrayiny' Naukovo-prakty'chny’j komentar: u 2 t. T. 2 [The Criminal Procedure Code of Ukraine. Scientific and Practical Commentary: in 2 vols. Vol. 2] (2012). Za zag. red. V. Ya. Taciya, V. P. Pshonky', A. V. Portnova. X.: Pravo. [in Ukrainian].

Lobojko L. M. (2014). Kry 'minal `ny j proces: pidruchny`k [Criminal process: a textbook]. K.: Vy`d. «Isty`na». [in Ukrainian].

Lucy`k V. V. (2009). Povernennya kry 'minal noyi spravy prokuroru zi stadiyi poperedn `ogo sudovogo rozglyadu: avtoref. dy`s... kand. yury`d. nauk: 12.00.09 [Return of a criminal case from a prosecutor from a preliminary trial stage: author's abstract. diss.... Cand. lawyer. Sciences: 12.00.09]. K. [in Ukrainian]. Lucy`k V. V. (2010). Povernennya kry`minal`noyi spravy` prokuroru $\mathrm{v}$ procesi rozglyadu kry`minal `ny`x sprav, napravleny`x dlya vy`rishennya py`tannya pro zvil`nennya osoby` vid kry`minal`noyi vidpovidal`nosti [Return of a criminal case to a prosecutor in the course of criminal proceedings aimed at resolving the issue of a person's release from criminal responsibility]. Chasopy`s Akademiyi advokatury 'Ukrayiny [Journal of the Academy of Advocacy of Ukraine], 9 (4), 1-5. [in Ukrainian].

Ponomarenko D. V. (2016). Bez elementiv nemaye zlochy`nu [There is no crime without the elements]. Zakon i biznes [Law and Business], 13 (1256), 9-13. [in Ukrainian].

Shmy`ndruk O. F. (2016). Pidgotovche provadzhennya v kry minal nomu procesi Ukrayiny': dy`s.... kand. yury`d. nauk: 12.00 .09 [Preparatory proceedings in the criminal process of Ukraine: dissertation.... Cand. lawyer. Sciences: 12.00.09]. Ostrog. [in Ukrainian]. 
Sy`za N.P. (2014). Zavdannya sudu v stadiyi pidgotovchogo provadzhennya $\mathrm{u}$ kry`minal`nomu procesi Ukrayiny` [The task of the court in the stage of preparatory proceedings in the criminal process of Ukraine]. Chasopy's Nacional nogo universy tetu "Ostroz ka akademiya». Seriya «Pravo» [Journal of the National University of Ostroh Academy. Law Series], 2 (10). <http://lj.oa.edu.ua/articles/2014/n2/14snpkpu.pdf>. [in Ukrainian].

Uxvala Apelyacijnogo sudu Rivnens`koyi oblasti u spravi \# 572/734/15-k vid 05 travnya 2015 roku [The decision of the Court of Appeal of Rivne Oblast in Case No. 572/734/15-k of 05 May 2015]. Yedy 'ny jo derzhavny ’j reyestr sudovy 'x rishen' [The only state register of court decisions]. <http:/ / www.reyestr.court.gov.ua/Review/43948528>. [in Ukrainian].

Uxvala Apelyacijnogo sudu Rivnens `koyi oblasti vid 24 lyutogo 2015 roku [The decision of the Court of Appeal of Rivne region of 24 February 2015]. Yedy'ny 'j derzhavny 'j reyestr sudovy'x rishen' [The only state register of court decisions]. <http:/ / www.reyestr.court.gov.ua/Review/42829960>. [in Ukrainian].

Uxvala Bilgorod-Dnistrovs`kogo mis ‘krajonnogo sudu Odes`koyi oblasti vid 28 bereznya 2019 r. [The decision of the Belgorod-Dnestrovsky City Court of Odessa region of March 28, 2019]. Rishennya dlya biznesu YouControl [Business decision - YouControl]. <https://youcontrol.com. ua/catalog/court-document/80819273/>. [in Ukrainian].

Uxvala Darny`cz`kogo rajonnogo sudu m. Ky`yeva vid 06 ly`pnya 2018 r. [Decree of the Darnytskyi District Court of Kyiv dated July 06, 2018]. Yedy 'ny `j derzhavny 'j reyestr sudovy 'x rishen ' [The Unified State Register of Judgments]. <http:/ / www.reyestr.court.gov.ua/Review/75416982>. [in Ukrainian].

Uxvala Golosiyivs`kogo rajonnogo sudu m. Ky`yeva vid 28.02.2018 roku [Resolution of the Holosiivskyi District Court of Kyiv dated 28.02.2018]. Yedy 'ny 'j derzhavny 'j reyestr sudovy 'x rishen' [The only state register of court decisions]. <http:/ / www.reyestr.court.gov.ua/Review/72509927>. [in Ukrainian].

Uxvala Korecz` kogo rajonnogo sudu Rivnens `koyi oblasti vid 19 serpnya 2015 roku [The decision of the Koretsky District Court of Rivne region of August 19, 2015]. Yedy 'ny ’j derzhavny `j reyestr sudovy 'x rishen' [The only state register of court decisions]. <http://www.reyestr.court.gov.ua/ Review/54974193>. [in Ukrainian].

Uxvala Ky`yivs`kogo rajonnogo sudu m. Odesy`vid 16.12.2016 roku [Resolution of the Kyiv District Court of Odessa dated 16.12.2016]. 
VERDICTUM - LIGA: ZAKON [VERDICTUM - LEAGUE: LAW]. <https://verdictum.ligazakon.net/document/63498750>. [in Ukrainian].

Uxvala Svyatoshy`ns`kogo rajonnogo sudu m. Ky`yeva vid 25 lyutogo 2014 roku [Decision of the Svyatoshinsky District Court of Kyiv of February 25, 2014]. Yedy 'ny ’j derzhavny ’j reyestr sudovy'x rishen ' [The only state register of court decisions]. <http:/ / www.reyestr.court.gov.ua/ Review/37333759>. [in Ukrainian].

Uxvala Xmel`ny`cz`kogo mis `krajonnogo sudu Xmel`ny`cz`koyi oblasti vid 26 grudnya 2014 roku [Decree of the Khmelnytsky City District Court of Khmelnytsky region of December 26, 2014]. Yedy `ny `j derzhavny j reyestr sudovy ' $x$ rishen' [The only state register of court decisions]. <http:/ / www.reyestr.court.gov.ua/Review/43352461>. [in Ukrainian].

\section{Анотація}

Пилипенко С. В. УхВала суду про повернення обвинувального акту, клопотання про застосуВання примусових заходіВ медичного або Виховного характеру прокурору: проблеми практики та нормативної регламентачї̈. - Стаття.

Стаття присвячена дослідженню проблем практики та правової регламентації винесення судами ухвал про повернення обвинувального акту, клопотань про застосування примусових заходів медичного чи виховного характеру прокурору. Обгрунтовано доцільність внесення наступних змін та доповнень до діючого КПК України, які сприятимуть ефективному провадженню та забезпечення прав і свобод осіб у нъому: доповнити п. 3 ч. 3 ст. 314 КПК «клопотанням про звільнення від кримінальної відповідальності», а також «додатками, передбаченими ицим Кодексом», щуо дасть правові підстави прийняття ухвали про їх повернення, якщз вони не відповідатимуть вимогам КПК; доповнити ст. 314 КПК нормою про направлення повернутого обвинувального акту, клопотання про застосування примусових заходів медичного або виховного характеру, клопотання про звільнення від кримінальної відповідальності, у випадку їх повторного подання після їх виправлення, тому судді (суду), який постановив ухвалу про їх повернення.

Ключові слова: ухвала суду; підготовче провадження; обвинувальнии акт; клопотання про застосування примусових заходів виховного або медичного характеру; судові рішення. 